\title{
Natural Product-Derived Drugs Based on $\beta$-Adrenergic Agents and Nucleosides
}

\author{
David J. Newman
}

\author{
Newman Consulting LLC, 664 Crestwood Road, 19087 Wayne-PA, USA
}

\begin{abstract}
This relatively short review demonstrates the very important role of the structures of the natural products adrenaline and relatives, in the design and subsequent approval of $\beta$-agonists and antagonists, and of modified nucleosides as anticancer, and in particular, antiviral agents against herpes (HSV), human immunodeficiency virus (HIV) and hepatitis C virus (HCV) that would not have been synthesized in the absence of knowledge of bioactive arabinose nucleosides.
\end{abstract}

Keywords: $\beta$-agonist, $\beta$-antagonist, nucleoside, natural product-based drug

\section{Introduction}

Although adrenalin(e) (epinephrine; 1 ) was first isolated from adrenal glands and reported in 1901 by Takamine, ${ }^{1}$ a full report of his work was published a century later in 2003 by Yamashima. ${ }^{2}$ This compound can be considered to have led to the concept of beta-adrenergic agents and their receptor subtypes, ${ }^{3-5}$ leading ultimately to the very significant number of agents used in hypertension and allergy and in particular, the beta-blocker, propranolol (2), ${ }^{6}$ which was a lineal chemical descendent of the earlier compound nethalide (3). ${ }^{7}$

Similarly, though later in time, nucleosides have been known as components of DNA (deoxyribonucleic acid) and RNA (ribonucleic acid) for a very significant number of years, dating from at least 1932 for the structure of adenosine ${ }^{8}$ with a fuller review of the purines and pyrimidines showing the state of the art at that time was published by Chromtzka in 1937. ${ }^{9}$ Their history as "leads to drugs" is more recent and aside from a very few agents where the base was modified chemically, no agents were synthesized until the reports from the Bergmann et al. ${ }^{10-12}$ at Yale in the early to middle 1950s of arabinose-substituted nucleosides with biological activities.

In this short review, it will be shown how these early discoveries have led to very significant drugs against cardiovascular disease and immediate allergy and other pulmonary diseases in the case of the adrenergic amine derivatives, and against viral diseases and cancer in the case of the nucleosides. None of which would have occurred if the basic biology and chemistry had not been elucidated

*e-mail: djnewman664@verizon.net in earlier days. This review is not meant to be exhaustive but will cover agents in use and some in late clinical trials status, where it will be shown where the original "ideas" came from in the chemical sense.

\section{The Biology of Adrenergic Agents}

Although not known at the time(s) of isolation and identification of the individual agents from animal tissues (including human), the biosyntheses of the agents easily demonstrates why drugs designed to resemble one or more of their biological effectors, often exhibit "side-effects" on other parts of these systems.

Scheme 1 shows the biosynthetic pathway for the production of the adrenergic agents from the amino acid tyrosine. As can be seen, the process goes through $L$-DOPA, then dopamine, norepinephrine (4; noradrenaline) to epinephrine (1; adrenaline), and it also shows the first non-specific $\beta$-agonist to go into clinical use, isoproterenol (5). The involvement of the dopaminergic agents in this pathway gives an indication as to why the agents used to activate (agonists) and block (antagonists) frequently exhibit "spillover" into related pathways. Thus the earlier and from the aspect of today, simplistic pharmacology statements made in the 1940s to probably the late 1970 s or so on specificity of adrenergic drugs, need to be reevaluated today on the basis of current knowledge of the molecular pharmacology of receptors that these agents interact with. However, that being said, the effects of these agents and their continued usage by physicians demonstrates that they still work.

The intention of this work is to discuss agents that fall into the categories of $\beta$-agonists and $\beta$-antagonists 
<smiles>N[C@H](Cc1ccc(O)cc1)C(=O)O</smiles>

L-Tyrosine

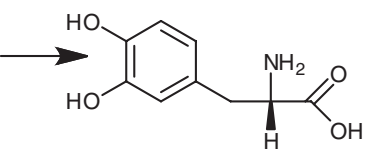

L-DOPA<smiles>CCCCCCN</smiles>

Dopamine<smiles>NC[C@H](O)c1ccc(O)c(O)c1</smiles>

4: Norepinephrine (noradrenaline)<smiles>CNC[C@H](O)c1ccc(O)c(O)c1</smiles>

Scheme 1. Biosynthesis of the adrenergic agents.

and will not cover other potential adrenergic interactions. The concept of $\beta$-agonists and antagonists arose from work performed as mentioned earlier by groups in the United Kingdom (UK) and the United States (US), with the initial report by Ahlquist in $1948 .{ }^{3}$ As shown below in Table 1 , there are currently three classes of $\beta$-receptors recognized by their responses to the two natural compounds epinephrine "E" (1) and norepinephrine "NE" (4), and the isopropyl analogue of "NE", the first synthesized $\beta$-agonist isoproterenol "Iso" (5) which was first used in Germany in $1940,{ }^{13-15}$ and which is still in use as a treatment for asthma. Further information on the $\beta_{3}$-receptor is given later in the review.

\section{Drugs Based on Epinephrine and Norepi- nephrine}

\section{1. $\beta$-Agonists}

In the early days of work in this area, as mentioned above, isoproterenol (5) was the gold standard for $\beta$-agonists and even though it is now close to 80 years since its initial synthesis (see references in Konzett's 1981 article $)^{15}$ and though it is now over 75 years since its initial use in 1940, it is still in the physician's armamentarium, though it is not selective in terms of the $\beta$-receptor subtypes.
Subsequently a significant number of "selective" $\beta$-agonists have entered the various pharmacopoeias used world-wide and they cover the three currently recognized $\beta$-agonist subtypes, though currently only one, as mentioned later, has been approved for the $\beta_{3}$-agonist subtype.

Early and some later examples are shown in Figures 1 (for $\beta_{1,2}$-agonists) and 2 (for $\beta_{3}$-agonists) where the date of approval by the US FDA (Food and Drug Administration) or its equivalent are shown in Table 2 (for all three types), with a note as to their "selectivity" against the various receptor subtypes (where known). Table 2 and the accompanying structures are not meant to be complete, they are simply examples drawn mainly from listings of such drugs in the reviews by Newman and Cragg. ${ }^{16-18}$

Inspection of the compounds in Figure 1 demonstrates how medicinal chemists built upon the basic structure of adrenaline (1) and noradrenaline (4) to first derive isoproterenol (5) a simple variation in the amino substituent (isopropyl for methyl in this case), but it still had nonspecific $\beta$-agonist activity being effectively equipotent against the $\beta_{1}$ and $\beta_{2}$ receptors as defined initially by Ahlquist ${ }^{3}$ in 1948, and there is now a third, or $\beta_{3}$ receptor identified. The later methodologies involved the use of radioligand displacement linked to activation of adenylate cyclase, and some of the early work on this technique, which is still in use, can be seen by inspection of the paper

Table 1. Pharmacological definition of $\beta$-receptors

\begin{tabular}{llcc}
\hline Receptor & Agonist & Tissue & Pharmacological response \\
\hline$\beta_{1}$ & Iso $>\mathrm{E}=\mathrm{NE}$ & juxtaglomerular cells heart & $\begin{array}{c}\text { increased renin secretion increased force } \\
\text { and rate of contraction }\end{array}$ \\
$\beta_{2}$ & Iso $>\mathrm{E}>>\mathrm{NE}$ & $\begin{array}{c}\text { smooth muscle (vascular and bronchial } \\
\text { gastrointestinal and genito-urinary) }\end{array}$ & relaxation \\
$\beta_{3}$ & Iso $=\mathrm{NE}>\mathrm{E}$ & adipose tissue & lipolysis \\
\hline
\end{tabular}

E: epinephrine; NE: norepinephrine; Iso: isoproterenol. 
1322

Natural Product-Derived Drugs Based on $\beta$-Adrenergic Agents and Nucleosides

J. Braz. Chem. Soc.<smiles>CNC[C@H](O)c1ccc(O)c(O)c1</smiles><smiles>NC[C@H](O)c1ccc(O)c(O)c1</smiles><smiles>CC(C)NCC(O)c1ccc(O)c(O)c1</smiles><smiles>CC(CCc1ccc(O)cc1)NCCc1ccc(O)c(O)c1</smiles>

1: Adrenaline (epinephrine)

4: Noradrenaline (norepinephrine)

Non-specific $\beta$-agonist

Non-specific $\beta$-agonist

5: Isoproterenol (isoprenaline) Non-specific $\beta$-agonist
6: Dobutamine, 1978 $\beta_{1}$-Agonist<smiles>C[C@H](CCc1ccc(O)cc1)NC[C@H](O)c1ccc(O)cc1</smiles>

7: Butopamine (1980+) $\beta_{1}$-Agonist

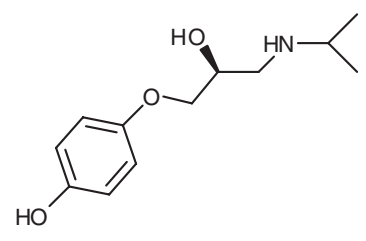

8: Prenalterol, UK, 1980s $\beta_{1}$-Agonist<smiles>O=C(NCCNCC(O)COc1ccc(O)cc1)N1CCOCC1</smiles>

9: Xamoterol, 1988

$\beta_{1}$-Agonist

Alzheimer's (preclinical 2015)<smiles>CC(C)(C)NCC(O)c1ccc(O)c(CO)c1</smiles>

10: Salbutamol, 1968 $\beta_{2}$-Agonist (active clinical trials 2015)

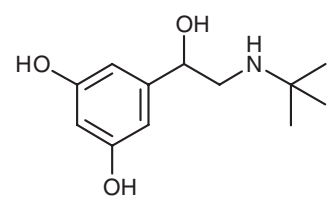

11: Terbutaline; 1970 $\beta_{2}$-Agonist

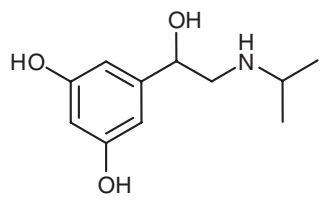

12: Metaproterenol (alupent) $\beta_{2}$-Agonist Launched France 1971 (withdrawn 2010)<smiles>CC(C)(C)NCC(O)c1ccc(O)c(CS(C)(=O)=O)c1</smiles>

13: Sulfonterol (1980?) $\beta_{2}$-Agonist<smiles>COc1ccc(C[C@@H](C)NC[C@H](O)c2ccc(O)c(NC=O)c2)cc1</smiles><smiles>CC(C)(C)NCC(O)c1cc(Cl)c(N)c(Cl)c1</smiles><smiles>O=C(O)c1ccc2ccccc2c1O</smiles>

14: Eformoterol; 1986

$\beta_{2}$-Agonist (also COPD)

15: Clenbuterol, 1986 $\beta_{2}$-Agonist (Pompe's disease, $\mathrm{PH} \mathrm{I} / \mathrm{II}$; 2015)

16: Salmeterol xinafoate; 1990 $\beta_{2}$-Agonist<smiles>CC(C)(C)NC[C@@H](O)c1ccc(O)c(CO)c1</smiles>

17: Levosalbutamol, 2000+ $\beta_{2}$-Agonist (Lupus PH II 2015)<smiles>COc1ccc(CC(C)(C)NC[C@H](O)c2cc(O)cc3c2OCC(=O)N3)cc1</smiles>

18: Olodaterol 2013/4 $\beta_{2}$-Agonist

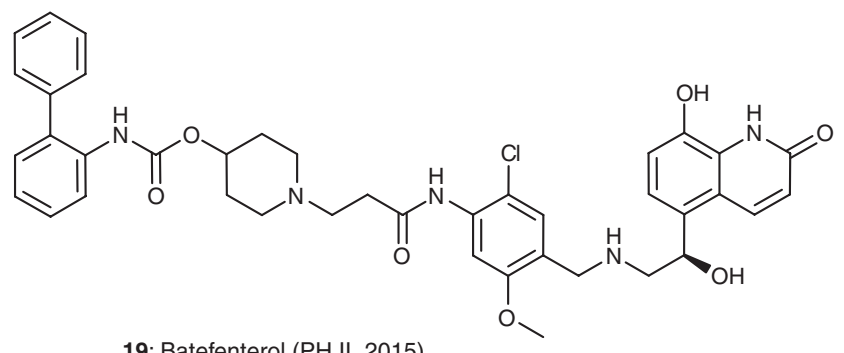

19: Batefenterol (PH II, 2015) $\beta_{2}$-Agonist (also muscarinic receptor antagonist)<smiles>Oc1ccc(CC2NCCc3cc(O)c(O)cc32)cc1</smiles>

20: Higenamine (norcoclaurine) $\beta_{2}$-Agonist (PH I, 2015I) Nandina domestica (leaves)

Figure 1. Non-specific $\beta$ and $\beta_{1}$ - and $\beta_{2}$ - specific agonists. 
Table 2. Approved and clinical Phase I-III $\beta$-receptor agonists

\begin{tabular}{lccc}
\hline Name & Number & Specificity & Date approved (if known \& comments) \\
\hline Dobutamine & $\mathbf{6}$ & $\beta_{1}$-selective & 1978 \\
Butopamine & $\mathbf{7}$ & $\beta_{1}$-selective & $1980+$ (not USA) \\
Prenalterol & $\mathbf{8}$ & $\beta_{1}$-selective & 1980s (UK) \\
Xamoterol & $\mathbf{9}$ & $\beta_{1}$-selective & 1988 (now preclinical in Alzheimer's) \\
Salbutamol & $\mathbf{1 0}$ & $\beta_{2}$-selective & 1968 (still active clinical trials) \\
Terbutaline & $\mathbf{1 1}$ & $\beta_{2}$-selective & 1970 (UK) \\
Metaproterenol & $\mathbf{1 2}$ & $\beta_{2}$-selective & 1971 (France; withdrawn 2010) \\
Sulfonterol & $\mathbf{1 3}$ & $\beta_{2}$-selective & 1980? (UK) \\
Eformoterol & $\mathbf{1 4}$ & $\beta_{2}$-selective & 1986 (Japan; now COPD) \\
Clenbuterol & $\mathbf{1 5}$ & $\beta_{2}$-selective & 1990 \\
Salmeterol & $\mathbf{1 6}$ & $\beta_{2}$-selective & 1986 (EU/Japan; now Phase I/II Pompe's disease) \\
Levosalbutamol & $\mathbf{1 7}$ & $\beta_{2}$-selective & early 2000s (now Phase II for lupus) \\
Olodaterol & $\mathbf{1 8}$ & $\beta_{2}$-selective & 2013/4 \\
Batefenterol & $\mathbf{1 9}$ & $\beta_{2}$-selective & Phase II (also Muscarinic receptors; COPD) \\
Higenamine (norcoclaurine) & $\mathbf{2 0}$ & $\beta_{2}$-selective & natural product Phase I \\
Mirabegron & $\mathbf{2 1}$ & $\beta_{3}$-selective & 2012 (Japan, US, EU) \\
Solabegron & $\mathbf{2 2}$ & $\beta_{3}$-selective & Phase II/III \\
Ritobegron & $\mathbf{2 3}$ & $\beta_{3}$-selective & Phase I ? \\
\hline
\end{tabular}

COPD: chronic obstructive pulmonary disease; USA: United States of America; UK: United Kingdom; EU: European Union.

by Bilezikian et al. ${ }^{19}$

Close inspection of the compounds listed in Figure 1, in particular compounds 6-9 demonstrated what could be considered most of the first tranche of molecules with $\beta_{1}$ activities, directed predominately against cardiac disease. The time lines for individual agents with "specificity" overlap however, since compounds with $\beta_{2}$ activities, directed against bronchial tissue, and thus often used in the treatment of asthma, were identified relatively early on with examples being compounds $\mathbf{1 0}$ to $\mathbf{1 3}$ and the levoisomer of 10, compound 17, being approved in 2000. All of these compounds definitely show their relationship to the natural catecholamines $(\mathbf{1}, \mathbf{4})$. What is of significance is that some compounds first approved in the early days of these classes of drugs, are still in current preclinical studies such as xanteranol (9) for Alzheimer's disease and salbutamol $(\mathbf{1 0}, \mathbf{1 7})$ in current clinical trials against other pulmonary diseases.

The interesting variations on isoproterenol (5), terbutaline (11) and metaproterenol (12) where the positions of the two ring hydroxyls moved from ortho to meta, and the activities were now predominately $\beta_{2}$ rather than non-specific, were approved in 1970 (UK) and in 1971 (France), respectively. The latter was withdrawn in 2010, but the reasons were not given in detail. Another modification of the catechol ring was demonstrated in sulfonterol (13), effectively sulfamylation of salbutamol
(10) which entered trials in the United Kingdom as both oral and injectable formulations but the final status is not available. I have therefore used "1980?" in Table 2.

Inspection of compounds 14 to $\mathbf{1 6}$ show some interesting variations on the base catecholamine structure with substitution of chlorine atoms mimicking terbutaline (11) and metaproterenol (12) in clenbuterol (15). This compound is now in Phase $\mathrm{I} / \mathrm{II}$ clinical trials against Pompe's disease. Efomoterol (14) is currently being tested against chronic obstructive pulmonary disease (COPD) in addition to its use in other bronchial diseases. Salmeterol (16) was the first approved agent that demonstrated that the amino group on the side chain could be radically extended and still maintain agonist activity and ring structures on both sides of the basal structure could also maintain activity as demonstrated by the very recent approval of olodaterol $(\mathbf{1 8}) .{ }^{20}$ The even more complex agent batefenterol (19) only has small components of the base pharmacophore in two dimensions, where it would be very interesting to see a crystal structure of this molecule in the agonist pocket, is currently in Phase II clinical trials and also demonstrates muscarinic activity. ${ }^{21}$ Finally in the $\beta_{2}$ "family", is the very interesting dihydroxy dihydroisoquinoline alkaloid, higenamine (20) isolated from the leaves of Nandina domestica ${ }^{22}$ which brings an interesting aspect to the relationship of the side chain amine and a hydroxyl group.

The more recently recognized adrenergic $\beta_{3}$ receptor is 
a member of the adrenergic receptor group of G-proteincoupled receptors. ${ }^{23}$ They are located primarily in the small intestine, adipose tissue and vascular endothelium. Here they are involved in lipolysis, glucose uptake, cardio-inhibition and relaxation of colon, esophagus and bladder. The human $\beta_{3}$ receptor gene has been localized to chromosome 8 (8p12-8p11.1).

The recognition of the existence of the $\beta_{3}$ receptor currently has one specific drug approved (mirabegon, 21) that is directed against overactive bladder/urinary incontinence $(\mathrm{OAB})$ and there is spill over into muscarinic receptor activities as well with this class of agents. ${ }^{24-28}$ In addition to this approved agent, solabegron (22) is in Phase II/III clinical trials with ritobegron (23) close to or in Phase I clinical trials. ${ }^{25,26,28}$ In all of these, the "base" pharmacophore can still be seen, but not as a catechol, which brings up some interesting thoughts as to the overlap between the $\beta_{3}$ and muscarinic receptors. Their structures are given in Figure 2.

\subsection{Beta-antagonists}

As mentioned in the introduction, the concept of $\beta$-receptors and for that matter, any other G-coupled receptor, is not new, but the molecular biology and knowledge of receptor protein structure is. The current database of receptors and their corresponding genes can be seen in the 2008 paper by Alexander et al. ${ }^{23}$ The concept in the early days was demonstrated by Ahlquist ${ }^{3}$ and then "defined" by Black et al. , $^{7}$ This concept implied that if there are activators (agonists) then there will be inactivators (antagonists), if they can be discovered.

As Black et al. ${ }^{6,7}$ demonstrated with the reports on propranolol (2) and its precursor, nethalide (3), there were small molecules that did exhibit such activities but against the then known $\beta_{1}$ and $\beta_{2}$ receptors without apparent selectivity. It should be borne in mind that this work was performed in the late 1950s to early 1960s time frame and if performed today, would probably have better defined the potential of these compounds. However, the impact of propranolol (2) upon the treatment of hypertension cannot be underestimated, even though it, like a majority of the early "competitors" were non-selective, hitting the then two known $\beta$-receptors equally.

In Figures 3 (non-selective) and 4 (selective) and Table 3 (all types), are shown a majority of the $\beta$-antagonists that have gone into clinical use, together with their dates of approval, their selectivities as defined by the drug approval systems in various countries, with non-selective meaning equipotent $\left(\beta_{1}\right.$ and $\left.\beta_{2}\right)$ and if selective, against which receptor. It should be realized that pharmacologically, a 100 fold difference in response is often used as a mark of selectivity. What should also be noted is that in later work, other activities are also noted with effects on serotonin receptors (HT5) or $\alpha$-receptors as the sophistication of assays increased. An excellent example would be that of nipradilol (36) which though approved in 1988 as a nonspecific antagonist, was also shown to have $\alpha$-blocking and nitroglycerin-like activities. ${ }^{29}$ Inspection of its structure (36) shows the potential for NO release under certain conditions, thus mimicking nitroglycerine treatment.

The basic pharmacophore of the non-specific $\beta$-antagonists $(\mathbf{2}, \mathbf{3}, \mathbf{2 4 - 3 8})$ can be seen as an aromatic (usually 2 rings and often planar) left hand side (all structures were redrawn to show this in Figure 4) with a side chain that in most cases has an ether linkage to the "normal" side chain of the $\beta$-agonists (1, 4 and $\mathbf{5}$ ). Inspection of the structures of the $\beta_{1}$-selective antagonists in Figure 3, specifically compounds 39-44, and 46, indicates<smiles>Nc1nc(CC(=O)Nc2ccc(CCNC[C@H](O)c3ccccc3)cc2)cs1</smiles><smiles>O=C(O)c1cccc(-c2cccc(NCCNC[C@H](O)c3ccccc3)c2)c1</smiles><smiles>CCOC(=O)COc1cc(C)c(CCN[C@H](C)[C@H](O)c2ccccc2)cc1C</smiles>

23: Ritobegron $\mathrm{PHI}$ ? $\beta_{3}$-agonist

Figure 2. $\beta_{3}$-Agonists. 
<smiles>CC(C)NCC(O)COc1cccc2ccccc12</smiles>

2: Propranolol; 1964 Non-selective<smiles>CC(C)NCC(O)c1ccc2ccccc2c1</smiles>

3: Nethalide (ICI 38,174) Non-selective<smiles>C=CCOc1ccccc1OCC(O)CNC(C)C</smiles>

24: Oxprenolol; 1968 Non-selective<smiles>CC(C)NCC(O)COc1cccc2[nH]ccc12</smiles>

25: Pindolol; 1970 Non-selective<smiles>CC1(C)CC1(C)NC[C@H](O)COc1nsnc1N1CCOCC1</smiles>

26: Timolol; 1974 Non-selective<smiles>CC(C)NCC(O)c1ccc(NS(C)(=O)=O)cc1</smiles>
Non-selective<smiles>CC(C)(C)NCC(O)COc1cc(Cl)ccc1Cl</smiles>

31: Cloranolol; 1981 Non-selective<smiles>CC(CCc1ccccc1)NCC(O)c1ccc(O)c(C(N)=O)c1</smiles>

28: Labetalol; 1977 NCT02426177 as 4/2015 Non-selective<smiles>CC(C)(C)NCC(O)COc1cccc2c1C[C@H](O)[C@H](O)C2</smiles>

29: Nadolol; 1978 Non-selective<smiles>CCNCC(O)COc1cccc2c1CCC(=O)N2</smiles>

30: Carteolol; 1980 Non-selective

NCT02105272, glaucoma,

PH. III, 2014<smiles>CC(C)(C)NC[C@H](O)COc1ccccc1C1CCCC1</smiles>

32: Penbutolol; 1981 Non-selective<smiles>CC(=O)Oc1c(C)cc(OCC(O)CNC(C)C)c(C)c1C</smiles>

33: Metipranolol; 1982 Non-selective, glaucoma
35: Tertalol; 1987 Non-selective $(-)$ isomer also a 5- HT1A antag, Ki 18 nM<smiles>CC(C)(C)NCC(O)COc1cccc2c1SCCC2</smiles>

34: Befunolol; 1984 Non-selective
Anti-glaucoma<smiles>CC(=O)c1cc2cccc(OCC(O)CNC(C)C)c2o1</smiles><smiles>CC(C)NCC(O)COc1cccc2c1OCC(O[N+](=O)[O-])C2</smiles>

36: Nipradilol; 1988 Non-selective Also vasodilatation<smiles>CC(C)NCC(O)COc1cn(C)c(=O)c2ccccc12</smiles>

37: Tilisolol; 1992 Non-selective<smiles>CCCCc1oc2ccc(NS(C)(=O)=O)cc2c1C(=O)c1ccc(OCCCN(CCC)CCCC)cc1</smiles>

38: Dronedarone; 2009 Non-selective

Figure 3. Non-selective $\beta$-antagonists.

that a compound closer in basic terms to compounds such as butopamine (7) and xamoterol (9) but with the ether linkage appears to have this type of pharmacologic action. The sole example to date of a $\beta_{2}$-selective antagonist, levobunolol (47) falls into molecules similar to sulfonterol (13) or olodaterol (18).

\subsection{Conclusions for $\beta$-agonist/antagonists}

Whatever their specific pharmacological effects, the very close relationship to the structures of the naturally 
<smiles>C=CCc1ccccc1OCC(O)CNC(C)C</smiles>

39; Alprenolol; 1967 $\beta_{1}$-Selective<smiles>COc1ccccc1OCCNCC(O)c1ccc(C)c(S(=O)(=O)O)c1</smiles>

42: Amosulalol; 1988 $\beta_{1}$-Selective<smiles>O[C@@H](CNC[C@@H](O)[C@H]1CCc2cc(F)ccc2O1)[C@H]1CCc2cc(F)ccc2O1</smiles>

45: Nevibolol; 1997 $\beta_{1}$-Selective<smiles>CC(C)NC[C@H](O)COc1cccc2[nH]ccc12</smiles>

48: Espindolol; PH II 2015

Cachexia with Stage III NSCLC

Figure 4. Selective $\beta$-antagonists.

occurring catecholamines $(\mathbf{1}, \mathbf{4})$, and to the other compounds in the biosyntheses of these agents (Scheme 1) leaves little doubt that the initial structural basis for the vast majority of these approved drugs was that of the natural product, followed by pharmacological testing.

What is also of note is that there are still specific and non-specific agents being synthesized and entering clinical trials. Examples are shown in Tables 2 and 3, and there are two compounds that have interesting properties in addition to their basic $\beta$-receptor activities.

The first is that of espindolol (48), which is a very simple compound where effectively the second unsubstituted ring of the naphthalene group in propranolol (2) has been replaced by a pyrrole, and then the isomers resolved. This particular agent has agonist and antagonist activity at $\beta 1, \beta 2$ and $\beta 3$ receptors as well as 5HT1A receptors, and these differ from those of the racemic parent. It has potential in the treatment of cachexia in cancer patients ${ }^{30}$ with non-small cell lung carcinoma (NSCLC) and has completed a successful Phase II clinical trial. ${ }^{31}$

The second is the natural product higenamine (28) which as mentioned above, has some very interesting activities $^{32}$ and structurally could be considered a substituted and ring-closed version of a shortened side chain version of adrenaline (1). It protects ischemia/reperfusion induced cardiac injury and myocyte apoptosis by activation of the $\beta_{2}$-AR/PI3K/AKT signaling pathway, thus may be a potential treatment for such diseases. It has completed a Phase I safety trial (NCT01451229) in China but no details have yet been published.

\section{Drugs Derived from Nucleosides}

As mentioned earlier in this article, substituted nucleosides have now become a major source of drugs against cancer and in particular, viral diseases. Initially, prior to roughly the 1960 s, drugs based on nucleosides were based upon either modification of the five naturally occurring purine or pyrimidine bases or substitution of these bases by another nitrogen containing molecule, and occasionally modifying the phosphate sidechain, with a very good example being citicoline (49) which was 
Table 3. Approved and clinical Phase I-III $\beta$-receptor antagonists

\begin{tabular}{|c|c|c|c|}
\hline Name & Number & Specificity & Date approved (if known \& comments) \\
\hline Propranolol & 2 & non-selective & 1964 \\
\hline Nethalide & 3 & non-selective & 1962 (Lancet report) \\
\hline Oxprenolol & 24 & non-selective & 1968 \\
\hline Pindolol & 25 & non-selective & 1970 \\
\hline Timolol & 26 & non-selective & 1974 \\
\hline Sotalol & 27 & non-selective & 1974 \\
\hline Labetalol & 28 & non-selective & 1977 \\
\hline Nadolol & 29 & non-selective & 1978 \\
\hline Carteolol & 30 & non-selective & 1980; NCT02105272, glaucoma, Phase III, 2014 \\
\hline Cloranolol & 31 & non-selective & 1981 \\
\hline Penbutolol & 32 & non-selective & 1981 \\
\hline Metipranolol & 33 & non-selective & 1982; (anti glaucoma treatment) \\
\hline Befunolol & 34 & non-selective & 1984; (anti glaucoma treatment) \\
\hline Tertalol & 35 & non-selective & 1987; (-) isomer also a 5- HT1A antagonist, Ki $18 \mathrm{nmol} \mathrm{L}^{-1}$ \\
\hline Nipradilol & 36 & non-selective & 1988; (also vasodilatation) \\
\hline Tilisolol & 37 & non-selective & 1992 \\
\hline Dronedarone & 38 & non-selective & 2009; (also $\alpha$-antagonist) \\
\hline Alprenolol & 39 & $\beta_{1}$-selective & 1967 \\
\hline Acebutolol & 40 & $\beta_{1}$-selective & 1973 \\
\hline Celiprolol & 41 & $\beta_{1}$-selective & 1982 \\
\hline Amosulalol & 42 & $\beta_{1}$-selective & 1988 (also $\alpha_{1}$-selective) \\
\hline Dilevalol & 43 & $\beta_{1}$-selective & 1989 (withdrawn, 1990) \\
\hline Epanolol & 44 & $\beta_{1}$-selective & 1992 \\
\hline Nevibolol & 45 & $\beta_{1}$-selective & 1997 \\
\hline Levobetaxolol & 46 & $\beta_{1}$-selective & 2000 (betaxolol, 1985; glaucoma) \\
\hline Levobunolol & 47 & $\beta_{2}$-selective & $1985\left(\right.$ glaucoma; $\left.200 \times \beta_{1}\right)$ \\
\hline Espindolol & 48 & agonist/antagonist $\beta 1, \beta 2, \beta 3$ and 5HT1A & 2015 (Phase II for cachexia with Stage III NSCLC \\
\hline
\end{tabular}

approved in Italy as an anti-Parkinson agent in 1967, and two where the base was completely altered. These were mizoribine (50) in Japan for lupus in 1984, and ribavirin (51) in the USA in 1986, well after the discovery of the arabinosine-containing agents described below.

A sea change in the biological chemistry of nucleosides came around 1960 when, as a result of the work of the Bergmann group, it became obvious that the then "current dogma" that the sugar on a nucleoside had to be either deoxyribose (52) or ribose (53) to show biological activity, was incorrect, as some of the molecules isolated by the Bergmann group, that did not have ribose, but its isomer arabinose (54) as the sugar, did have biological activity. ${ }^{10-12}$

With the identification of spongouridine (55) and spongothymidine (56) from the sponge extracts came the realignment of dogma to include arabinose as a sugar that did not remove biological activity. These two compounds can be considered to be the prototypes of all the nucleoside analogues that have crossed the antiviral and antitumor stages since that time, as chemists then began to use modifications of the bases and then once these demonstrated activity modification of the sugar moieties were not far behind, even using acyclic variations rather than regular pentoses.

These early experiments led to a vast number of derivatives that were tested extensively as antiviral and antitumor agents over the next six decades as shown in Tables 4-6 and Figures 6-8. It should be noted at this point that the comments for some of the compounds mentioned below, will not follow chronologically from those shown above, due to the listings being organized by disease and year within disease

In a review in 1991, Suckling ${ }^{33}$ demonstrated how such structures evolved in the Wellcome laboratories, leading ultimately to molecules such as azidothymidine (74) or 


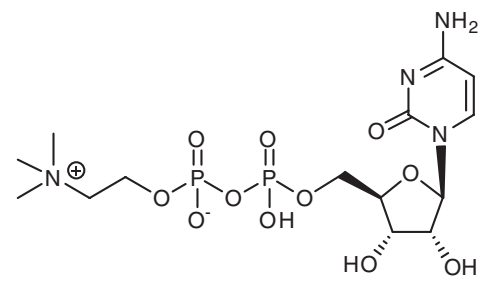

49: Citicoline

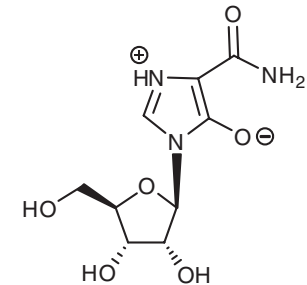

50: Mizoribine<smiles>NC(=O)c1ncn([C@@H]2O[C@H](CO)[C@@H](O)[C@H]2O)n1</smiles>

51: Ribavirin

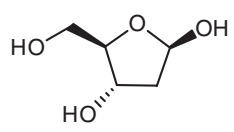

52: Deoxyribose

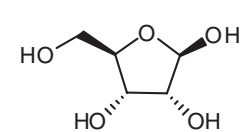

53: $D$-Ribose

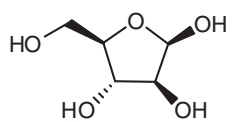

54: D-Arabinose

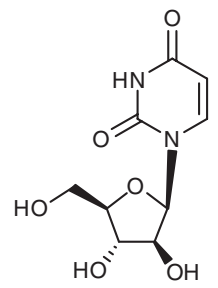

55: Spongouridine

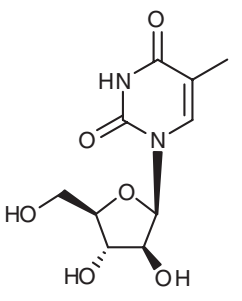

56: Spongothymidine

Figure 5. Selected examples of modified nucleosides.

AZT, though no direct mention was made of the original "privileged structures from natural sources". Demonstrating an interesting temporal reversal where chemists synthesized a compound that was later found in nature, in 1960, Lee et $a l .{ }^{34}$ reported the synthesis of arabinosyladenine (Ara-A or vidarabine, 72) as a potential antitumor agent, with a later report showing production by fermentation of S. antibioticus. ${ }^{35}$ Then it was isolated and purified from the Mediterranean gorgonian Eunicella cavolini by the Cimino et al..$^{36}$ in 1984 . To this list can be added cytarabine (Ara-C; 57), which was synthesized by Evans et al. ${ }^{37}$ following the reports of the early discoveries above. It was covered in work by Pizer and Cohen ${ }^{38}$ on its metabolism and on the potential mechanism as an antileukemic agent in the report by Chu and Fischer. ${ }^{39}$

Since those early days, a multiplicity of agents have been approved world-wide for agents against viral diseases, in particular anti-human immunodeficiency virus (HIV), and antitumor agents. These have involved substitutions in all parts of the molecules, both the base and the sugar. In Tables 4-6, and Figures 6-8, a majority of the molecules that have been approved, their dates of approval and the specific disease(s) involved are shown. The tables are ordered by the activity that the agent was approved for, with antitumor agents first (Table 4, Figure 6 and compounds 57-68) including three agents (69-71) currently in Phase III trials, two for leukemia and one for liver cancer.

\section{Antitumor Agents Based on Nuclesosides}

As can be seen from inspection of these structures, modifications of both the sugar and the base have occurred.
In some, just the sugar $(\mathbf{5 7}, \mathbf{6 3}, \mathbf{7 0})$, in some just the base $(62,64,65,67,68)$, and in some, both $(60,64,66,69$, 71). Further discussion is not needed of these examples as effectively all have been synthesized with the knowledge that changes can be made in all areas of the nucleoside framework while still maintaining biological activity. All of these can legitimately be considered as being derived from base natural product structures.

\section{Antiviral Agents Based on Nucleosides}

Inspection of the approved antiviral agents in Table 5 and Figure 7 (72-88) again with a Phase III compound (89) in trials for postherpetic pain, aptly demonstrates how the knowledge that modification of the sugar moiety could lead to novel bioactivities. Perhaps the best examples for this comment are two very early drugs in this section, vidarabine (72) and acyclovir (73). In the first case, the change of the sugar to arabinose (as mentioned earlier, this was coincidental with the reports of the Bergmann group, though whether Lee et al. ${ }^{34}$ had prior knowledge is unknown), yielded a compound that was designed to be an antitumor agent but gained fame as an anti-herpes simplex drug. Similarly, perhaps the most "famous" of these early nucleosides was azidothymidine (AZT; 74). Again this was synthesized as an antitumor agent but happened to be available as the HIV epidemic occurred and following testing at the US NCI, it turned out to be the first effective agent against HIV infection, even though it was quite toxic.

By completely truncating the sugar, acyclovir (73) and its two close congeners famciclovir (77) and valacyclovir (79) were synthesized and approved for treatment of 
Table 4. Approved and clinical Phase III antitumor agents (post arabinoside discovery)

\begin{tabular}{lccc}
\hline Name & Number & Disease & Date approved (current status comment) \\
\hline Cytarabine (Ara-C) & $\mathbf{5 7}$ & cancer & 1969 (USA) \\
Fluorofur & $\mathbf{5 8}$ & cancer & 1972 (USSR) prodrug of 5-FU \\
Enocitabine & $\mathbf{5 9}$ & cancer & 1984 (Japan) leukemia \\
Fludarabine & $\mathbf{6 0}$ & cancer & 1991 (USA) \\
Deoxycoformycin & $\mathbf{6 1}$ & cancer & 1992 (USA) natural product \\
Cladribine & $\mathbf{6 2}$ & cancer & 1993 (USA) \\
Gemcitabine & $\mathbf{6 3}$ & cancer & 1995 (UK) \\
Capecitabine & $\mathbf{6 4}$ & cancer & 1998 (USA) \\
5-Azacytidine & $\mathbf{6 5}$ & cancer & 2004 (USA) \\
Clofarabine & $\mathbf{6 6}$ & cancer & 2004 (USA) \\
Decitabine & $\mathbf{6 7}$ & cancer & cancer \\
Nelarabine & $\mathbf{6 8}$ & cancer & 2006 (USA) T-cell leukemia \\
Sapacitabine & $\mathbf{6 9}$ & cancer & 2015 (USA) Phase III leukemia \\
MB-7133 & $\mathbf{7 0}$ & cancer & 2015 (China) Phase III liver cancer \\
Guadecitabine & $\mathbf{7 1}$ & 2015 (USA) Phase III leukemia
\end{tabular}

USA: United States of America; UK: United Kingdom; EU: European Union; USSR: Union of Soviet Socialist Republics.

herpes (HSV). These two molecules were designed as effective prodrugs of acyclovir, with increased oral availability. Although HIV is perhaps the "best known" viral disease in the late 1980s to date, other major worldwide viral diseases are hepatitis B (for which there is a vaccine) and hepatitis $\mathrm{C}(\mathrm{HCV})$, for which there is not. Chronic HCV infection leads to very significant liver damage and often ends with hepatic cancer/death. In fact, until recently, the only "cure" in the West for severe $\mathrm{HCV}$ infection was a liver transplant. In countries such as Thailand and Korea there are high infection levels of $\mathrm{HCV}$ and effects, particularly in Thailand, of significant mortality when HCV positive patients have aflatoxins in their diet, which occurs quite easily due to fungal infection of feedstuffs in tropical areas.

In 2013, came the approval of the masked nucleotide sofosbuvir (88) plus ribavirin (51) as "the" treatment for $\mathrm{HCV}$, with the ability to cure the vast majority of treated HCV patients in approximately 12 weeks of oral treatment. The history and potential of this compound and closely related compounds have recently been published and these papers should be consulted by interested readers. ${ }^{40-44}$ It should also be mentioned that significant numbers of antiviral drugs against HIV are now delivered as preadjusted combinations of reverse transcriptase, integrase and protease inhibitors, which have the potential to reduce this disease to chronic status. An example uses emtricitabine (84) and tenofovir (82) plus the non-nucleoside reverse transcriptase inhibitor (rilpivirine; structure not shown as not a nucleoside or derivative) approved in 2011 by the FDA as Complera ${ }^{\circledR}$. An earlier combination had three modified nucleosides, azidothymidine (72), lamivudine (78) and abacavir (80) under the trade name Trizvir ${ }^{\circledR}$.

\section{Nucleosides with Adenosine Agonist/ Antagonist Activities}

In Figure 8 and Table 6, three molecules that are adenosine receptor agonists/antagonists (90-92) are shown. In this disease area, of these compounds, regadenoson (90) which was approved in 2008, shows only a modification in the adenosine base, thus falling into the same category as the first nucleoside-based agents used before the Bergmann discoveries. In contrast, the other two, trabodenoson (91) in Phase III clinical trials and cangrelor (92) which was approved in 2015 by the FDA as an antiplatelet agent to stop clotting during the insertion of stents into coronary arteries ${ }^{45}$ have modifications in both the base and sugar moieties but it should be noted that in all three cases, the sugar is $D$-ribose (53).

\section{In Conclusion}

From the data provided in the sections above, the very significant influence of the well known natural products, the sympathomimetic catecholamines, adrenaline and noradrenaline, and the basic nucleosides, now with arabinose, from DNA and RNA can be seen in agents for 
<smiles>Nc1ccn([C@@H]2O[C@H](CO)[C@@H](O)[C@H]2O)c(=O)n1</smiles>

57: Cytarabine (Ara-C)

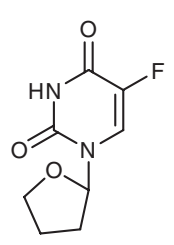

58: Fluorofur

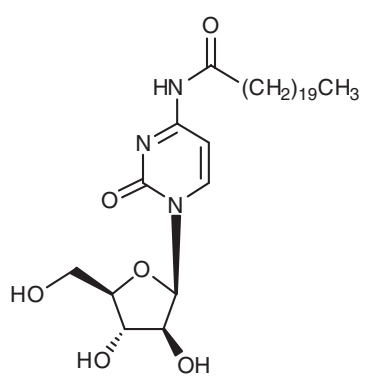

59: Enocitabine<smiles>Nc1nc(F)nc2c1ncn2[C@@H]1O[C@H](COP(=O)(O)O)[C@@H](O)[C@H]1O</smiles>

60: Fludarabine phosp hate<smiles>OC[C@H]1O[C@@H](n2cnc3c2N=CNC[C@H]3O)C[C@@H]1O</smiles>

61; Deoxycoformycin<smiles>Nc1nc(Cl)nc2c1ncn2C1C[C@H](O)[C@@H](CO)O1</smiles>

62: Cladribine<smiles>Nc1ccn([C@@H]2O[C@H](CO)[C@@H](O)C2(F)F)c(=O)n1</smiles>

63: Gemcitabine<smiles>CCCCCOC(=O)Nc1nc(=O)n([C@@H]2O[C@H](C)[C@@H](O)[C@H]2O)cc1F</smiles>

64: Capecitabine<smiles>Nc1ncn([C@@H]2O[C@H](CO)[C@@H](O)[C@H]2O)c(=O)n1</smiles>

65: 5-Azacytidine<smiles>Nc1nc(Cl)nc2c1ncn2[C@@H]1O[C@H](CO)[C@@H](O)[C@H]1F</smiles>

66: Clofarabine

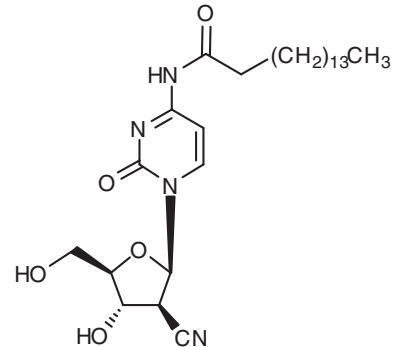

69. Sapacitabin<smiles>Nc1ccn([C@@H]2O[C@H](COP3(=O)OCC[C@@H](c4ccncc4)O3)[C@@H](O)[C@H]2O)c(=O)n1</smiles>

70: MB-7133

67: Decitabine

68: Nelarabine<smiles>N#[N+]OP(=O)(OC[C@H]1O[C@H](n2cnc(N)nc2=O)C[C@@H]1O)O[C@@H]1C[C@H](n2cnc3c(=O)[nH]c(N)nc32)O[C@@H]1CO</smiles>

71: Guadecitabine so dium

Figure 6. Antitumor agents (nucleosides post Bergmann).

hypertension and asthma and in the very important areas of anticancer and antiviral agents.

The importance of the discoveries made by the Bergmann group $^{10-12}$ in the 1950 s cannot be overestimated as it demonstrated that the then current dogma as to what was or was not bioactive in modifying nucleosides was incorrect. What is very "interesting" bearing in mind the reports by Davis $^{35}$ and Cimino et al. ${ }^{36}$ as to sources of the arabinose- containing nucleoside vidarabine (72), is the recent report from the Gerwick group in 2015 that spongosine and other related compounds were found in the bacterium Vibrio harveyi isolated from the same sponge species, and in the same geographic area as Bergmann almost 65 years earlier. ${ }^{46}$ Thus this report, coupled to those from Davis ${ }^{35}$ and Cimino et al. ${ }^{36}$ definitively implies a microbial link in the production of these metabolites worldwide, whether terrestrial or marine. 
<smiles>Nc1ncnc2c1ncn2[C@@H]1O[C@H](CO)[C@@H](O)[C@H]1O</smiles>

72; Vidarabine (Ara-A)<smiles>Nc1nc2c(ncn2COCCO)c(=O)[nH]1</smiles>

73; Acyclovir<smiles>Cc1cn([C@@H]2C[C@H](N)[C@@H](CO)O2)c(=O)[nH]c1=O</smiles>

74; Azidothymidine (AZT)<smiles>Nc1ccn([C@@H]2CC[C@@H](CO)O2)c(=O)n1</smiles>

75; Zalcitabine<smiles>O=c1[nH]c(=O)n([C@@H]2O[C@H](CO)[C@@H](O)[C@H]2O)cc1/C=C/Br</smiles>

76; Sorivudine<smiles>CC(=O)OCC(CCn1cnc2cnc(N)nc21)COC(C)=O</smiles>

77; Famciclovir<smiles>Nc1nc(NC2CC2)c2ncn(C3CC4C=C[C@@H](C4)C3)c2n1</smiles>

80: Abacavir<smiles>Cc1cn([C@@H]2C[C@@H](N)[C@@H](CO[PH](=O)O)O2)c(=O)[nH]c1=O</smiles>

81: Nikavir<smiles>Nc1ccn(C2OCCS2)c(=O)n1</smiles>

78; Lamivudine<smiles>CC(C)[C@H](N)C(=O)OCCOCn1cnc2c(=O)[nH]c(N)nc21</smiles>

79; Valacyclovir<smiles>CC(C)OC(=O)OCOP(=O)(CO[C@@H](C)Cn1cnc2c(N)ncnc21)OCOC(=O)OC(C)C</smiles>

82: Tenofovir disoproxil<smiles>O=c1[nH]c(=O)n([C@@H]2C[C@H](O)[C@@H](CO)O2)cc1/C=C/Br</smiles>

83: Brivudine<smiles>Nc1nc(=O)n(C2CSC(CO)O2)cc1F</smiles>

84: Emtricitabine<smiles></smiles>

85: Entecavi<smiles>Cc1cn(C[C@@H]2O[C@H](CO)[C@@H](O)[C@@H]2F)c(=O)[nH]c1=O</smiles>

86: Clevudine<smiles>Cc1cn(C[C@H]2C[C@H](O)[C@H](CO)O2)c(=O)[nH]c1=O</smiles>

87: Telbivudine<smiles>CC(C)OC(=O)[C@H](C)NP(=O)(OC[C@H]1O[C@@H](n2ccc(=O)[nH]c2=O)C(C)(F)[C@@H]1O)Oc1ccccc1</smiles>

88: Sofosbuvir<smiles>CCCc1ccc(-c2cc3cn([C@H]4C[C@@H](O)[C@@H](COC(=O)[C@@H](N)C(C)C)O4)c(=O)nc3o2)cc1</smiles>

89: FV-100

Figure 7. Antiviral agents (nucleosides post Bergmann). 
Table 5. Approved and clinical Phase III antiviral agents (post Bergmann)

\begin{tabular}{|c|c|c|c|}
\hline Name & Number & Disease & Date approved (current status comment) \\
\hline Vidarabine (Ara-A) & 72 & antiviral & 1976 (USA) HSV \\
\hline Acyclovir & 73 & antiviral & 1981 (USA) HSV \\
\hline Azidothymidine (AZT) & 74 & antiviral & 1987 (USA) HIV initially designed for cancer treatment \\
\hline Zalcitabine & 75 & antiviral & 1992 (USA) HIV \\
\hline Sorivudine & 76 & antiviral & 1993 (Japan), HSV; withdrawn rapidly due to toxicity with 5FU; currently Phase II trials \\
\hline Famciclovir & 77 & antiviral & 1994 (USA) HSV \\
\hline Lamivudine & 78 & antiviral & 1995 (USA) HIV, 1998 (USA) HBV \\
\hline Valaciclovir & 79 & antiviral & 1995 (USA) HSV (prodrug of acyclovir) \\
\hline Abacavir & 80 & antiviral & 1998 (USA) HIV RT inhibitor \\
\hline Nikavir & 81 & antiviral & 1999 (Russia), HIV RT Inhibitor \\
\hline Tenofovir & 82 & antiviral & 2001 (USA) HBV \\
\hline Brivudine & 83 & antiviral & 2001 (Germany) HSV \\
\hline Emtricitabine & 84 & antiviral & 2003 (Germany) HIV \\
\hline Entecavir & 85 & antiviral & 2005 (USA) HBV \\
\hline Clevudine & 86 & antiviral & 2005 (Korea) HBV \\
\hline Telbivudine & 87 & antiviral & 2006 (Switzerland) HBV \\
\hline Sofosbuvir & 88 & antiviral & 2013 (USA) HCV \\
\hline FV-100 & 89 & antiviral & 2015 (USA) Phase III herpetic pain \\
\hline
\end{tabular}

${ }^{a}$ Selectively monophosphorylated by HSV thymidine kinase; HSV: herpes; HIV: human immunodeficiency virus; HCV: hepatitis C virus; USA: United States of America.<smiles>CNC(=O)c1cnn(-c2nc(N)c3ncn([C@H]4O[C@H](CO)[C@@H](O)[C@H]4O)c3n2)c1</smiles>

90: Regadenoson<smiles></smiles>

91: Trabodenoson<smiles>CSCCNc1nc(SCCC(F)(F)F)nc2c1ncn2[C@@H]1O[C@H](COP(=O)([O-])OP(=O)([O-])C(Cl)(Cl)P(=O)([O-])O)[C@@H](O)[C@H]1O</smiles>

92: Cangrelor

Figure 8. Adenosine receptor agonists/antagonists.

Table 6. Approved/clinical Phase III adenosine agonist/antagonist agents (post Bergmann)

\begin{tabular}{lccc}
\hline Name & Number & Disease & Date approved (current status comment) \\
\hline Regadenoson & $\mathbf{9 0}$ & A2A agonist & 2008 (USA) \\
Trabodenoson & $\mathbf{9 1}$ & A1A agonist & 2015 (USA) Phase III glaucoma \\
Cangrelor & $\mathbf{9 2}$ & angina & 2015 (USA) \\
\hline
\end{tabular}

USA: United States of America.

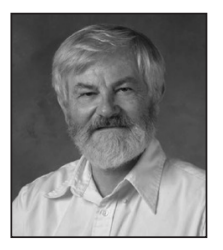

David J. Newman (DPhil, Sussex, 1968, microbial chemistry) retired in January 2015 as Chief of the Natural Products Branch (NPB) at the US NCI. He came to the USA in 1968 and following 23 years in academia and industry, joined the NPB in 1991, becoming Chief in 2005. He has over 175 publications covering natural products as drugs or leads thereto. He was President (2012-2013) of the American Society of Pharmacognosy (ASP) and was elected a fellow of the ASP in 2014. He currently has a small consulting company in the US covering drug discovery.

\section{References}

1. Takamine, S.; Am. J. Pharm. 1901, 73, 523.

2. Yamashima, T.; J. Med. Biogr. 2003, 11, 95.

3. Ahlquist, R. P.; Am. J. Physiol. 1948, 153, 586.

4. Lands, A. M.; Arnold, A.; McAuliff, J. P.; Luduena, F. P.; Brown Jr., T. G.; Nature 1967, 214, 597. 
5. Lands, A. M.; Luduena, F. P.; Buzzo, H. J.; Life Sci. 1967, 6, 2241.

6. Black, J. W.; Crowther, A. F.; Shanks, R. G.; Smith, L. H.; Dornhorst, A. C.; Lancet 1964, 283, 1080.

7. Black, J. W.; Stephenson, J. S.; Lancet 1962, 280, 311.

8. Levene, P. A.; Tipson, R. S.; J. Biol. Chem. 1932, 94, 809.

9. Chrometzka, F.; Annu. Rev. Biochem. 1937, 6, 211.

10. Bergmann, W.; Feeney, R. J.; J. Am. Chem. Soc. 1950, 72, 2809.

11. Bergmann, W.; Feeney, R. J.; J. Org. Chem. 1951, 16, 981.

12. Bergmann, W.; Burke, D. C.; J. Org. Chem. 1955, 20, 1501.

13. Konzett, H.; Naunyn-Schmiedebergs Arch. Pharmakol. 1940, 197, 27.

14. Konzett, H.; Naunyn-Schmiedebergs Arch. Pharmakol. 1940, 197, 41.

15. Konzett, H.; Trends Pharmacol. Sci. 1981, 2, 47.

16. Newman, D. J.; Cragg, G. M.; Snader, K. M.; J. Nat. Prod. 2003, 66, 1022.

17. Newman, D. J.; Cragg, G. M.; J. Nat. Prod. 2007, 70, 461.

18. Newman, D. J.; Cragg, G. M.; J. Nat. Prod. 2012, 75, 311.

19. Bilezikian, J. P.; Dornfeld, A. M.; Gammon, D. E.; Biochem. Pharmacol. 1978, 27, 1445.

20. Cazzola, M.; Matera, M. G.; Drugs Future 2013, 38, 235.

21. Hughes, A. D.; Chen, Y.; Hegde, S. S.; Jasper, J. R.; Jaw-Tsai, S.; Lee, T. W.; McNamara, A.; Pulido-Rios, M. T.; Steinfeld, T.; Mammen, M.; J. Med. Chem. 2015, 58, 2609.

22. Tsukiyama, M.; Ueki, T.; Yasuda, Y.; Kikuchi, I. H.; Akaishi, T.; Okumura, H.; Abe, K.; Planta Med. 2009, 75, 1393.

23. Alexander, S. P. H.; Mathie, A.; Peters, J. A.; Br. J. Pharmacol. 2008, 153, S1.

24. Abe, Y.; Ota, E.; Endo, T.; Murakami, M.; Kobayashi, M.; Pharmazie 2014, 69, 881.

25. Ellsworth, P.; Fantasia, J.; Expert Opin. Investig. Drugs 2015, $24,413$.

26. Giarenis, I.; Robinson, D.; Cardozo, L.; Drugs 2015, 75, 1707.

27. Sacco, E.; Bientinesi, R.; Tienforti, D.; Racioppi, M.; Gulino, G.; D’Agostino, D.; Vittori, M.; Bassi, P.; Expert Opin. Drug Discovery 2014, 9, 433.

28. Thiagamoorthy, G.; Giarenis, I.; Cardozo, L.; Expert Opin. Investig. Drugs 2015, 24, 1299.

29. Kanno, M.; Araie, M.; Koibuchi, H.; Masuda, K.; Br. J. Ophthalmol. 2000, 84, 293.
30. Griva, M.; Cor Vasa, in press, DOI:10.1016/j.crvasa.2015.08.003.

31. Beadle, J.; Stewart Coast, A. J.; Fuang, H. G.; Prabhash, K.; von Haehling, S.; Brown, R.; Anker, S. D.; Ann. Oncol. 2014, 25, Abst. 6878.

32. Wu, M.-P.; Zhang, Y.-S.; Zhou, Q.-M.; Xiong, J.; Dong, Y.-R.; Yan, C.; Pharmacol. Res. 2016, 104, 115.

33. Suckling, C. J.; Sci. Prog. 1991, 75, 323.

34. Lee, W. W.; Benitez, A.; Goodman, L.; Baker, B. R.; J. Am. Chem. Soc. 1960, 82, 2648.

35. Davis, P.; GB pat. 1,159,290 1969.

36. Cimino, G.; de Rosa, S.; de Stefano, S.; Experientia 1984, 40, 339.

37. Evans, J. S.; Musser, E. A.; Mengel, G. D.; Forsblad, K. R.; Hunter, J. H.; Proc. Soc. Exp. Biol. Med. 1961, 106, 350.

38. Pizer, L. I.; Cohen, S. S.; J. Biol. Chem. 1960, 235, 2387.

39. Chu, M. Y.; Fischer, G. A.; Biochem. Pharmacol. 1962, 11, 423.

40. Murakami, E.; Tolstykh, T.; Bao, H.; Niu, C.; Micolochick Steuer, H. M.; Bao, D.; Chang, W.; Espiritu, C.; Bansal, S.; Lam, A. M.; Otto, M. J.; Sofia, M. J.; Furman, P. A.; J. Biol. Chem. 2010, 285, 34337.

41. Gane, E. J.; Stedman, C. A.; Hyland, R. H.; Ding, X.; Svarovskaia, E.; Symonds, W. T.; Hindes, R. G.; Berrey, M. M.; N. Engl. J. Med. 2013, 368, 34.

42. Coats, S. J.; Garnier-Amblard, E. C.; Amblard, F.; Ehteshami, M.; Amiralaei, S.; Zhang, H.; Zhou, L.; Boucle, S. R. L.; Lu, X.; Bondada, L.; Shelton, J. R.; Li, H.; Liu, P.; Li, C.; Cho, J. H.; Chavre, S. N.; Zhou, S.; Mathew, J.; Schinazi, R. F.; Antiviral Res. 2014, 2014, 119.

43. de Clercq, E.; Biochem. Pharmacol. 2014, 89, 441.

44. Gable, J. E.; Acker, T. M.; Craik, C. S.; Chem. Rev. 2014, 114, 11382.

45. Kubica, J.; Kozinski, M.; Navarese, E. P.; Tantry, U.; Kubica, A.; Siller-Matula, J. M.; Jeong, Y. H.; Fabiszak, T.; Andruszkiewicz, A.; Gurbel, P. A.; Curr. Med. Res. Opin. 2014, 30, 813.

46. Bertin, M. J.; Schwartz, S. L.; Lee, J.; Korobeynikov, A.; Dorrestein, P. C.; Gerwick, L.; Gerwick, W. H.; J. Nat. Prod. 2015, 78, 493.

Submitted: January 18, 2016

Published online: March 4, 2016 